\title{
A Short History of Cattle and Range Management in Hawai'i
}

\author{
Kepa Maly and Bruce A. Wilcox
}

$\mathrm{T}$ The introduction of cattle along with other grazing stock has significantly influenced the natural and cultural ecology of Hawai' $i$. A tropical insular ecosystem with a particularly unique natural and cultural history, this influence has been perhaps more ecologically profound in Hawai' $i$ than is typical. Alteration of the landscape and cultural practices that followed the introduction and expansion of cattle in the $19^{\text {th }}$ Century were nonetheless accommodated by the existing indigenous system of natural resource values and management practices. Ranching persisted as a viable industry, an accepted part of land and natural resources management, and an integral element of Hawaii's rich cultural landscape throughout most of the present century. Yet range management practice based on these indigenous values and practices has begun to be displaced by changes in ranch ownership or management practices during the last three decades. As a consequence of this, and the current drought, it appears the ecological sustainability and economic viability of cattle ranching may be going the way of the cultural legacy of the paniolo (or paniola) and the traditional knowledge and practices were the underpinning of the industry until recently.

\section{Traditional Polynesian and Western Resource Management: Conflict and Assimilation}

In pre-western contact Hawai ' $i$, all land and natural resources were held in trust by the high chiefs (ali' $i$ 'ai ahupua' $a$ or ali ' $i$ 'ai moku). The rights of use of the lands and resources were given to the hoa'aina (native tenants), at the prerogative of the ali $i$ and their representatives. Boundaries of lands were defined, and individuals living within given аһириа' $a$ (native land divisions, usually extending from the sea to the mountains) were responsible for the wise use of the resources within their home land. The thought shared among many kupuna (elders) and Hawaiian people today-E malama $i \mathrm{ka}$ 'aina, a e malama ho ' $i \mathrm{ka}$ 'aina ia 'oe (care for the land, and the land, in turn, shall care for you), is one that is centuries old and is rooted in the spirituality of the Hawaiian people.

Upon western contact, a largely new perspective on Hawaiian land was introduced - that of its value for extractableexportable resources-first as a source of provision for ships; and second as source of trade items, such as 'iliahi (sandalwood). In 1778, European boars, goats, rams, and ewes were introduced by Captain Cook. Offered as "gifts," a motivating factor was to leave a breeding stock to supply other foreign ships (Beaglehole 1967:276, 578-579). Later, in 1793, cattle were brought to Hawai ' $i$ by Captain Vancouver (Vancouver 1967). Given as gifts to Kamehameha I, the cattle were first let off at Kawaihae (then at Kealakekua), and were placed under a ten-year kapu to protect them and allow them to reproduce (Kamakau 1961:164). Between 1793 and 1811, new stock were added, and the numbers of cattle increased dramatically. Cattle and other introduced stock were rapidly becoming a problem to the native population and upland forests. Prior to this, a well-developed indigenous agriculture system (the most advanced in Polynesia), supporting an impressively large human population, had already altered the landscape through the cutting and burning of forest for crops, and the gathering of wood for fuel. Locally this affected micro-climates, erosion, and soil moisture at the lower elevations long before European contact (Cuddihy and Stone 1990). Yet the islands' upland forests remained largely intact.

By the 1830s, however, the upland forests had been stripped of sandalwood and the land began to show signs of significant impacts due to overgrazing and trampling, as well as the clearing made for collection and transportation of the 'iliahi. By the 1840s, free roaming cattle, sheep, and goats were having such a severe impact on the native dwellings (e.g., eating thatched houses) and consuming the produce of the agricultural fields, that most of the families who remained upon the land built stone walls around their residence and gardens (cf. Land Commission Award Testimonies, 1848-1850). The "pa hale" (house lots enclosed with walls or fences) are recorded in many of the Land Commission Awards. Reverend Lorenzo Lyons noted that by 1847 , "two thirds of Waimea has been converted to government pasture" (Doyle 1953:48). He wrote:

People are compelled to leave their cultivated spots and seek distant corners of the woods beyond the reach of the roaming cattle sheep and goats. But the cattle follow, and soon destroy the fruit of their labor. There is a despairing spirit among my people, and great suffering among them...

Lyons also noted that the forests and weather had changed over the years of his residence (since 1832 till his death in 1886). The once famous gale-force " $m u$ muku" winds which blew down the plains towards the ocean did not blow as frequently:

Waimea of an evening is a perfect cloud of dust. The soil is remarkably dry, and so extremely fine that water does not even seem to wet it...Cattle destroying the forest has changed the mumuku. It was formerly so strong that natives always lashed canoes to the rocks, stakes, or trees at Kawaihae (Doyle 1953:49).

That the free roaming cattle were having an impact not only on the cultivated lands of the native tenants, but also on 


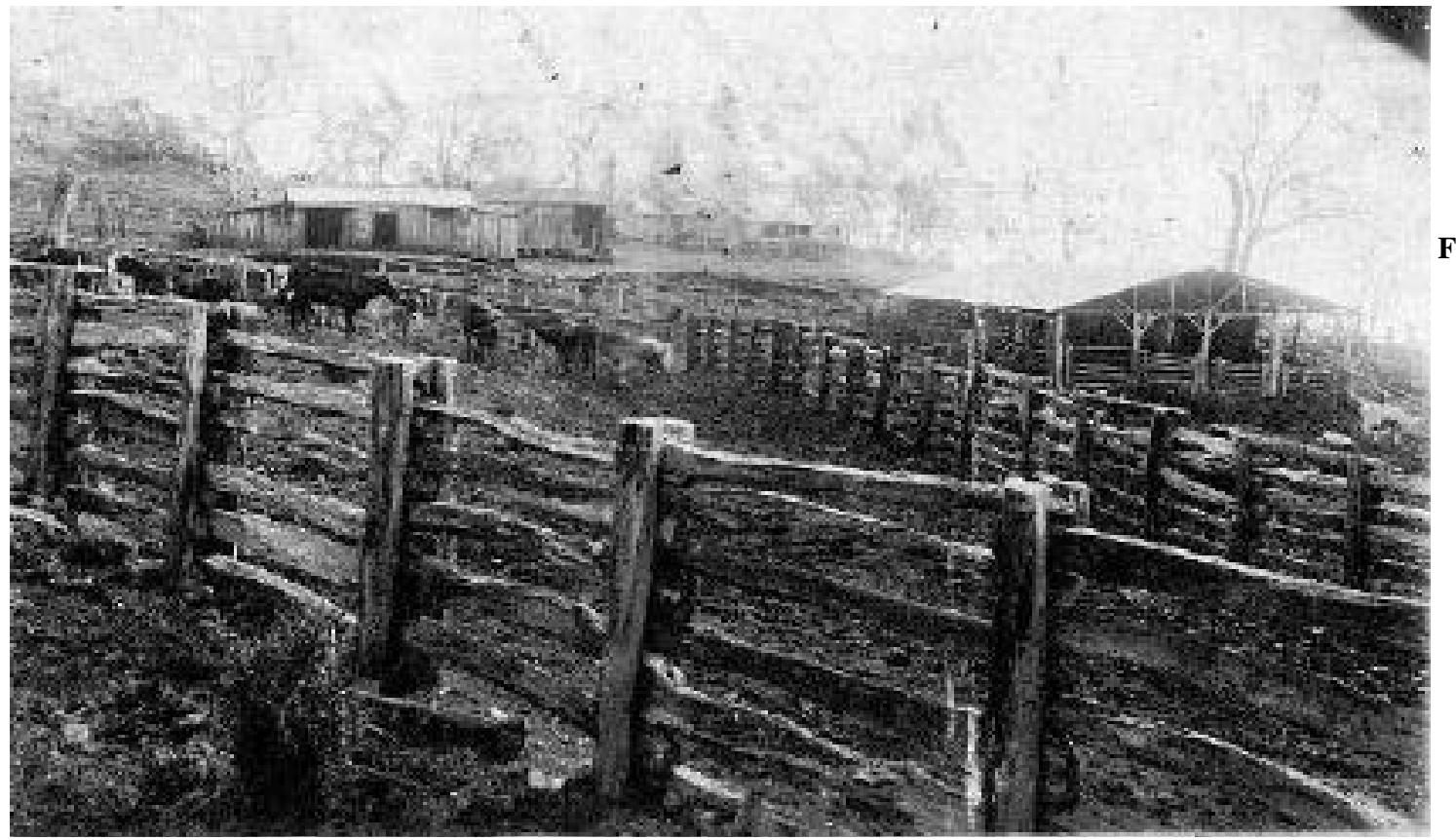

Fig. 1. Pu'u O'o Ranch House ca. 1898, Mauna Kea Slopes, Hawai'i. Note the na tive timber-primarily mamane-cut for fencing, contributing to demise of forest. Courtesy of Toshio Imoto.

the remaining forests (Figure 1) was documented in 1856 by Kingdom land surveyor, Curtis Lyons, son of Reverend Lyons as well:

It is in the memory of many foreigners now living here, when the whole of these plains were covered with thick wood... Where hardly a tree is to be seen for miles, we were informed by an old resident that twenty-five years ago he lost himself with his team in the woods (Lyons in Forbes 1991:54).

The younger Lyons also remarked that there was far more rain at Waimea than there is now.

By the second half of the $19^{\text {th }}$ Century, Hawaii's the ahириа' $a$ land management system had collapsed due to a combination of factors - the redistribution of land control as part of the Great Mahele and the decimation of the indigenous population by smallpox being the chief causes - though land stewardship remained an important cultural value. In an attempt to address the by now devastating impact of livestock, on September 19, 1876, King David Kalakaua signed into law, the "Act for the Protection and Preservation of Woods and Forests". This act authorized the Minister of the Interior to set apart and protect from "damage by trespass of animals or otherwise, such woods and forest lands, the property of government... best suited for the protection of water resources..." (Hawaii Laws Chapter XXX:39). The Minister of the Interior was authorized to appoint a superintendent of woods and forests.

The Act was further defined by the Legislature of the Hawaiian Kingdom, approved by Queen Lili 'uokalani on January 4, 1893, establishing the Bureau of Agriculture and Forestry, which was absorbed by the Board of Commissioners of Agriculture and Forestry in 1900. (Hawaii State Archives-Com 2, Box 11). By this time, one far thinking commissioner (Boyd 1901), recognized and described the critical function of upland forest reserves as watershed, and the role of livestock in destruction of native forest via a cascade of ecological changes beginning with loss of understory vegetation and soil moisture, and ending with the invasion of aggressive non-native vines and grasses that "choke out" and prevent regeneration of the native ecosystem. Since then the impact of cattle and other non-native ungulates on native forest has been widely documented (Cuddihy and Stone 1990).

\section{The Rise and Fall of Range Management and Ranching}

The first attempts to control cattle herds began in 1815 when Kamehameha I hired foreigners to work the animals
(Barrera and Kelly 1974:44). By 1830 Kamehameha III had vaqueros (Mexican-Spanish cow hands) brought to the islands to teach the Hawaiians the skills of herding and handling cattle (Strazar 1987:20; and Kuykendall and Day 1961:96). The vaqueros found the Hawaiians to be capable students, and by the 1870 s, the Hawaiian cowboy came to be known as the "paniola" for the Espanola (Spanish) vaqueros who had been brought to the islands.

During the period leading up to the late 1850 s, nearly all of the cattle belonged either to the King, the government, other chiefs close to the King, and a few foreigners who had been granted the right to handle the cattle (cf. Henke 1929:19-20). By 1851 there were around 20,000 cattle on the island of Hawai 'i, and approximately 12,000 of them were wild (Henke 1929:22). With the development of ranching throughout the rest of the $19^{\text {th }}$ Century and well into the $20^{\text {th }}$ Century, the proportion of cattle in managed herds gradually grew while wild cattle declined, although some still persist today. However, many ranching operations continued clearing of upland native forest, particularly on Hawai 'i and West Maui where ranches expand rangeland tens of thousands of acres upslope (Cuddihy and Stone 1990).

Though not without significant and 


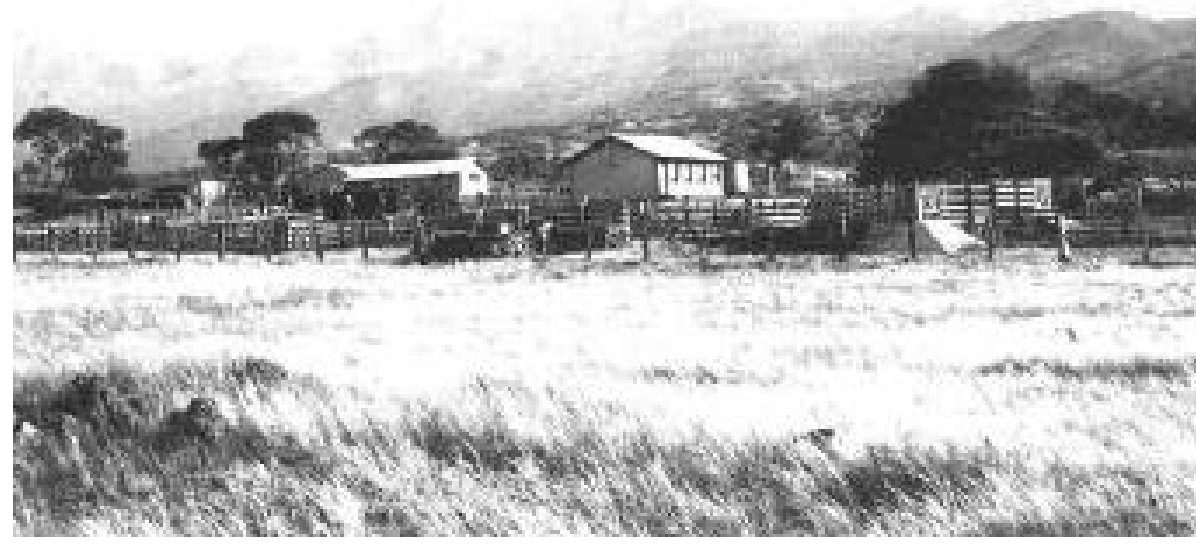

Fig 2. Ranch House on the northeastern slope of Mauna Kea, Hawai'i. Note the pasture land in the foreground, and remnant native forest in background, ca. 1920. Photo No. 1019, Courtesy of the Hawaiian Historical Society.

continued impacts and assault on native forest and forest reserves, by midCentury it might be said that Hawai ' $i$ had come to terms with cattle ranching, in the sense that range management practices were in place and had become part of the ranching and paniolo culture that incorporated stewardship values (Figure 2). As ranching evolved, so had a paniolo culture, which integrated many native Hawaiian elements, as is evident today from song and legend. This included a concern and respect for the land by paniolo, who managed the cattle in long grazing rotations.

By the 1960 s to 70 s, however, even these "neo-traditional" values and practices began breaking down with significant changes in ranch ownership and management practices. Some of Hawaii's ranches were bought-out by non-residents and large corporations whose owners had no connection to the land and sought to maximize short term profits. Until this time ranchers managed their herds according to a predictable seasonal rain and long term rotations. According to long time ranch managers and paniolos (personally communicated to Maly and whose commentaries are documented in detailed oral histories in various archives) these ranch management changes coincided with or brought about marked changes in climate, herd management, and culture. It became dryer and rainfall less pre- dictable. Rotation periods were drastically shortened, and herd management less intensive. Most unfortunately, the paniolo culture declined, and with it, a knowledge of traditional management practices and an understanding range conservation presently all but lost from most operations throughout the Hawaiian Islands.

With the current "official" drought in its third or forth year, the effects of this gradual transition in ownership, management, weather, and culture have become more abundantly clear. Even the historically most successful cattle operations, such as the Parker Ranch, have significantly reduced herd size and are in a precarious economic position. Meanwhile, one of the other large historic operations, Molokai Ranch, whose once extensive dry forest covered slopes have given way to virtually bare ground and extensive gully erosion, has transitioned to the "eco-adventure tourism" business. Glossy brochures feature photos of happy tourist families astride mountain bikes with red dirt covered hills in the background. Somehow, in this burgeoning era of high tech outdoor equipment and adventure escapism, clever marketing has been able to transform an ecological calamity (at least from the authors' perspective ) into a mountain biker's paradise.

\section{References}

Boyd, E. 1901. Report on a visit to the Kohala and Hamakua Districts by the Commissioner of Public Lands, submitted to Governor Dole.

Barrera, W. Jr., and M. Kelly. 1974. Archaeological and Historical Surveys of the Waimea to Kawaihae Road Corridor, Island of Hawaii. B. P. Bishop Museum, Honolulu. Prepared for the Department of Transportation, State of Hawaii.

Beaglehole, J.C. 1967. The Journals of Captain James Cook on His Voyages of Discovery. London: The Hakluyt Society. (Edited from the original manuscripts by J.C. Beaglehole.)

Cuddihy, L.W. and C.P. Stone. 1990. Alteration of Native Hawaiian Vegetation: Effects of Humans, Their Activities and Introductions. University of Hawaii Press, Honolulu.

Doyle, E.L. 1945. Makua Laiana: The Story of Lorenzo Lyons. Compiled from the manuscript journals, 1832-1886. Honolulu: Honolulu Star-Bulletin.

Forbes, D.W. 1991. A Pictorial Tour of Hawaii, 1850-1852; Water Colors, Paintings, and Drawings by James Gay Sawkins; with an account of his life and travels by David W. Forbes. Book Club of California, No. 197.

Hawai'i State Archives. Misc. Letters and communications cited in text. Honolulu.

Henke, L.A. 1929. A Survey of Livestock in Hawaii. University of Hawaii. Research Publication, No. 5.

Kamakau, S.M. 1961. Ruling Chiefs of Hawaii. Honolulu: Kamehameha Schools Press.

Kuykendall, R.S., and A.G. Day. 1970. Hawaii: A History; From Polynesian Kingdom to American Statehood. Englewood Cliffs: Prentice-Hall, Inc. (New Revised Edition).

Strazar, M.D. 1987. Ranching in Hawai 'i. In Na Paniolo o Hawai 'i. Lynn Martin (ed.). State Foundation on Culture and the Arts and the Honolulu Academy of Arts.

Vancouver, G. 1967. A Voyage of Discovery to the North Pacific Ocean, and Round the World, Volumes 1-3. London: Robinsons and Edwards.

Authors are Kumu Pono Associates, Program in Ecology, Evolution, and Conservation Biology, University of Hawai ' $i$ 